\title{
Surface Roughness Report and 3D Surface Analysis of Hybrid Metal Matrix Composites (MMC) During Abrasive Water Jet (AWJ) Cutting
}

\author{
Ashish Kumar Srivastava, Shashi Prakash Dwivedi, Nagendra Kumar Maurya ${ }^{*}$, Rohit Sahu
}

Department of Mechanical Engineering, G.L. Bajaj Institute of Technology and Management, Greater Noida, GB Nagar 201306, India

Corresponding Author Email: nagendra.maurya@glbitm.org

https://doi.org/10.18280/rcma.303-407

Received: 23 November 2019

Accepted: 16 January 2020

\section{Keywords:}

hybrid MMC, A359 aluminum alloy, surface

roughness, $3 D$ profile view, abbreviations

\begin{abstract}
The conventional machining of engineering hard materials like composites is a challenging task due to rapid tool wear and high machining cost. In this context, the non-conventional machining such as abrasive waterjet cutting is mostly utilized for the cutting of such hard materials due to its tremendous machining outcomes. Here an attempt is made to cut the previously developed sample of hybrid metal matrix composite $\mathrm{A} 359 / \mathrm{B} 4 \mathrm{C} / \mathrm{Al}_{2} \mathrm{O}_{3}$ by abrasive waterjet machining process. Three different samples with change proportions of reinforcement from $2 \%$ to $4 \%$ were used in this study to create the flat machined surfaces. The surface roughness profile and 3D surface detailing are generated through the microprof FRT machine and inbuilt measuring sensor. Result revels that rough cutting with the average surface roughness value ranges from 7 to $9 \mu \mathrm{m}$ for the selected samples. The machined surface is full of cutting traces with some of macro pores of size $1.2 \mathrm{~mm}$ to $1.8 \mathrm{~mm}$ observed by 3D profile views.
\end{abstract}

\section{INTRODUCTION}

The advancement in the technology increases the demand of new class of engineering materials. In this view, the development of metal matrix composites (MMCs) was introduced from last few decades [1]. The excellent properties of MMCs such as improved mechanical, thermal and physical properties as well as its light weight and anticorrosion eminence makes it suitable for most of the engineering applications [2, 3]. However, the machining results of MMCs are not satisfactory reported by most of the authors $[4,5]$. The problem arises with conventional cutting or turning are the rapid tool wear due to occurrence of tough coarse particles in the MMCs and larger machining time, which increases the overall machining cost $[6,7]$. Nowadays non-conventional machining is mostly utilized for the machining of such hard materials like composites [8]. The reason behind this selection is the non-physical contact between the tool and workpiece and negligible cutting forces [9]. In the field of non-conventional process, abrasive water jet (AWJ) is most suitable application because it does not require the conductance of the material to be cut [10].

The mechanism of cutting by AWJ process was based on the plastic deformation. A jet of high-pressure water including high velocity abrasive particles strikes the workpiece surface, which removes the required excess materials [11]. The process is controlled with the support of its variable like abrasive mass flow rate, traverse speed, nozzle speed, type of abrasive, work piece rotation etc. [12]. The major advantage of the AWJ process is its cold cutting (there is no heat generated during the cutting operation [13]. The process is also capable for larger material removal rate and improved fatigue strength of the machined surface due to the pinning action on the workpiece surface [14]. Machining with AWJ can be applied for turning, drilling and milling as per requirement of the industry. However, the surface roughness of the AWJ machined surface is high compared to the other machining processes reported by most of the authors [15-17]. This is due the fact that the ploughing nature of cutting was observed with plastic deformation. Another reason for high surface roughness is the creation of long thin grooves on the machined surface and random cutting traces.

Several studies have been carried out related to machining of hard material through conventional process. From archival literature it can be concluded that machining of hybrid metal matrix composite is difficult through conventional machining operation. Surface roughness of the machined components through conventional machining is high. To overcome the machining difficulty if hard material an attempt is made to cut the previously developed sample of hybrid metal matrix composite $\mathrm{A} 359 / \mathrm{B}_{4} \mathrm{C} / \mathrm{Al}_{2} \mathrm{O}_{3}$ by abrasive waterjet machining process. The experiments were performed on waterjet machine of model CNC WJ2020B-1Z-D. Three different samples with change proportions of reinforcement from $2 \%$ to $4 \%$ were used in this study to create the flat machined surfaces. The surface roughness profile and 3D surface detailing are generated through the microprof FRT machine and inbuilt measuring sensor.

\section{EXPERIMENTAL PROCEDURE}

In this investigation $\mathrm{A} 359 / \mathrm{B}_{4} \mathrm{C} / \mathrm{Al}_{2} \mathrm{O}_{3}$ hybrid metal matrix composite material is developed through electromagnetic stir casting process. A359 is used as matrix material whereas $\mathrm{B}_{4} \mathrm{C}$ and $\mathrm{Al}_{2} \mathrm{O}_{3}$ were used as reinforcement martial. Due to the 
reinforcement of ceramic particle tensile strength and hardness of the composite are significantly improved.

However, toughness properties of the hybrid composite are decreased due to the reinforcement. For proper mixing, reinforcement materials are preheated to at $260^{\circ} \mathrm{C}$ for five hours to remove the moisture content. The proportion details of matrix and reinforcement materials are illustrated in Table 1. The schematic line diagrams of electromagnetic stir casting setup used for the manufacturing of hybrid composite are demonstrated in Figure 1. Three different samples were developed with change proportion of each reinforcement from $2 \%$ to $4 \%$ by weight. Mechanical properties, i.e. tensile strength, hardness and toughness are evaluated. Specimen samples for evaluation of mechanical properties are prepared according to ASTM standards. For sample preparation from developed hybrid metal matrix composite AWJ machine is used. It has capability to cut precisely. The experimental work is performed on waterjet machine of model CNC WJ2020B-1Z-D. After testing the mechanical properties of the samples are given in Table 2. The technical specifications of the machine are given in Table 3. The width of the workpiece samples was taken $20 \mathrm{~mm}$. The other technological parameters for is fixed during the experimental work these are as follows: water pressure $300 \mathrm{MPa}$, transverse speed $50 \mathrm{~mm} / \mathrm{min}$, abrasive mass flow rate 300 $\mathrm{g} / \mathrm{min}$, water tube nozzle diameter $0.33 \mathrm{~mm}$, stand-off distance $2 \mathrm{~mm}$ and Australian garnet abrasive of $80 \mathrm{mesh}$ size.

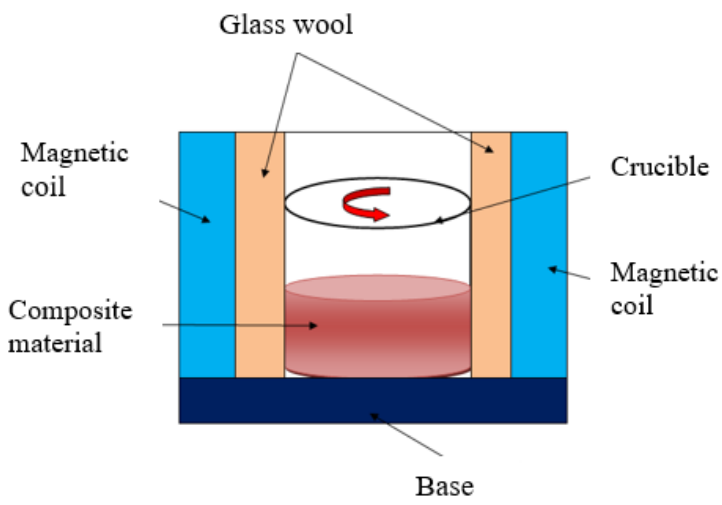

Figure 1. Line diagram of electromagnetic stir casting setup

Table 1. Proportion details of matrix and reinforcement material

\begin{tabular}{cccc}
\hline $\begin{array}{c}\text { Sample } \\
\text { no }\end{array}$ & $\begin{array}{c}\text { Matrix } \\
\text { material }\end{array}$ & $\begin{array}{c}\text { Reinforcement } \\
\text { Material 1 }\end{array}$ & $\begin{array}{c}\text { Reinforcement } \\
\text { Material 2 }\end{array}$ \\
\hline 1 & $\mathrm{~A} 359$ & $\mathrm{~B} 4 \mathrm{C} 2 \%$ & $\mathrm{Al}_{2} \mathrm{O}_{3} 2 \%$ \\
2 & $\mathrm{~A} 359$ & $\mathrm{~B} 4 \mathrm{C} 3 \%$ & $\mathrm{Al}_{2} \mathrm{O}_{3} 3 \%$ \\
3 & $\mathrm{~A} 359$ & $\mathrm{~B} 4 \mathrm{C} 4 \%$ & $\mathrm{Al}_{2} \mathrm{O}_{3} 4 \%$ \\
\hline
\end{tabular}

Table 2. Basic mechanical properties of the tested hybrid MMCs

\begin{tabular}{cccc}
\hline Sample & $\begin{array}{c}\text { Strength } \\
(\mathbf{M P a})\end{array}$ & $\begin{array}{c}\text { Hardness } \\
(\mathbf{H R C})\end{array}$ & $\begin{array}{c}\text { Toughness } \\
\left(\mathbf{J}^{2} \mathbf{m}^{2}\right)\end{array}$ \\
\hline $\begin{array}{c}\mathrm{a}-\mathrm{A} 359 / 2 \% \mathrm{~B}_{4} \mathrm{C} \\
/ 2 \% \mathrm{Al}_{2} \mathrm{O}_{3}\end{array}$ & 112.6 & 52.5 & 10.6 \\
$\begin{array}{c}\mathrm{b}-\mathrm{A} 359 / 3 \% \mathrm{~B} 4 \mathrm{C} \\
13 \% \mathrm{Al}_{2} \mathrm{O}_{3}\end{array}$ & 129.5 & 58.6 & 9.3 \\
$\begin{array}{c}\mathrm{c}-\mathrm{A} 359 / 4 \% \mathrm{~B} 4 \mathrm{C} \\
/ 4 \% \mathrm{Al}_{2} \mathrm{O}_{3}\end{array}$ & 141.2 & 61.4 & 9.1 \\
\hline
\end{tabular}

Table 3. Technical specification of AWJ machine

\begin{tabular}{cc}
\hline $\begin{array}{c}\text { Parameters of CNC table: CNC } \\
\text { WJ2020B-1Z-D }\end{array}$ & Value \\
\hline Range of work $(\mathrm{X}, \mathrm{Y}, \mathrm{Z}) \mathrm{mm}$ & $2000,2000,300$ \\
Range of Transverse speed $(\mathrm{m} / \mathrm{min})$ & 20 \\
Cut accuracy $(\mathrm{mm})$ & 0.03 \\
Weight of machine $(\mathrm{Kg})$ & 5000 \\
Axes resolution $(\mathrm{X}, \mathrm{Y}, \mathrm{Z}) \mathrm{mm}$ & 0.001 \\
\hline
\end{tabular}

Table 4. Surface Roughness measurement parameters (EN ISO 4287)

\begin{tabular}{cc}
\hline Fixed parameter & Value \\
\hline Noise filter cut-off, ls: & $8 \mu \mathrm{m}$ \\
Form removal: & Line \\
Cut-off wavelength, lc: & $2.5 \mathrm{~mm}$ \\
Number of cut-offs: & 5 \\
Evaluation length: & $12.5 \mathrm{~mm}$ \\
\hline
\end{tabular}

Microprof FRT machine is used to generate the surface roughness report and 3D surface profile for detailing purpose. The technical specification for the measuring purpose is given in Table 4 as per ISO 4287.

\section{RESULT AND DISCUSSION}

All the surface roughness parameters of the machined surface of developed hybrid metal matrix composite have been investigated. The physical image of samples cut by AWJ process is shown in Figure 2. It is observed from the images that the machined surface is profound with cutting traces for all tested samples. These traces are randomly oriented, some of them are long while other traces are short and oblique orientations. Few macro-pores are also observed on the machined surface. These are due to the pulling of hard particles from the machined surface during plastically deformed phase which were not cut when they come in the line of cutting.

The surface profile report is generated for all three samples. Figures 3, 4 and 5 describe the surface roughness profile, material ratio curve and roughness report in all roughness parameters. The figure revels that the average surface roughness ranges from $7.32 \mu \mathrm{m}$ to $8.2 \mu \mathrm{m}$ for sample (a), $7.58 \mu \mathrm{m}$ to $8.80 \mu \mathrm{m}$ for sample (b) $8.35 \mu \mathrm{m}$ to $8.99 \mu \mathrm{m}$ for sample (c). The other surface roughness parameters are also varied in the same order for all three samples.

It is observed that there is a rough cutting by AWJ process. This is due to the fact that during the AWJ process, high speed and high-pressure waterjet with full of abrasive strikes the workpiece surface. Due to which the surface gets plastically deformed and cutting action seems like ploughing of workpiece surface. There are lots of cutting traces are also observed on the machined surface which are randomly oriented and also oblique from the direction of jet flow. The striking of jet creates the long furrows on the machined surface. These are the processes increases the surface roughness slightly higher than other similar processes. It is also observed that while increasing the reinforcement percentage in the HMMCs the surface roughness values are increases. It is due to the fact that while increasing the reinforcement percentage, the hardness of the MMCs are increases, hence the interaction time of jet striking on a 
particular area of the workpiece surface is increases to increase the plastic deformation against the hardness. This larger time for striking increase the number of cutting traces hence roughness value increases.

Figures 6, 7 and 8 show the 3D surface profile for detailing of the machined surface of samples $\mathrm{A} 359 / 2 \% \mathrm{~B}_{4} \mathrm{C} / 2 \% \mathrm{Al}_{2} \mathrm{O}_{3}$, $\mathrm{A} 359 / 3 \% \mathrm{~B}_{4} \mathrm{C} / 3 \% \mathrm{Al}_{2} \mathrm{O}_{3}$ and $\mathrm{A} 359 / 4 \% \mathrm{~B}_{4} \mathrm{C} / 4 \% \mathrm{Al}_{2} \mathrm{O}_{3}$ respectively. The $3 \mathrm{D}$ surface profile of the machined surface shows the cutting traces oriented parallel to the direction of jet flow. However, some of the traces are oblique to the direction of jet flow and also randomly oriented. Macro-pores are observed on the machined surfaces of all three samples. This is due to the fact that while jet strikes the workpiece surface the material gets plastically deformed, however the reinforcement particles which are come in the line of jet cutting are pulled out from the matrix material instead of cutting. Due to which the macro-pores are observed on the machined surface. As the percentage of reinforcement increases the possibility of pulling out of more particles from the machined surface are increases. Therefore, the larger number of macro-pores is observed in Figure 8 compared to Figure 6 and 7 .

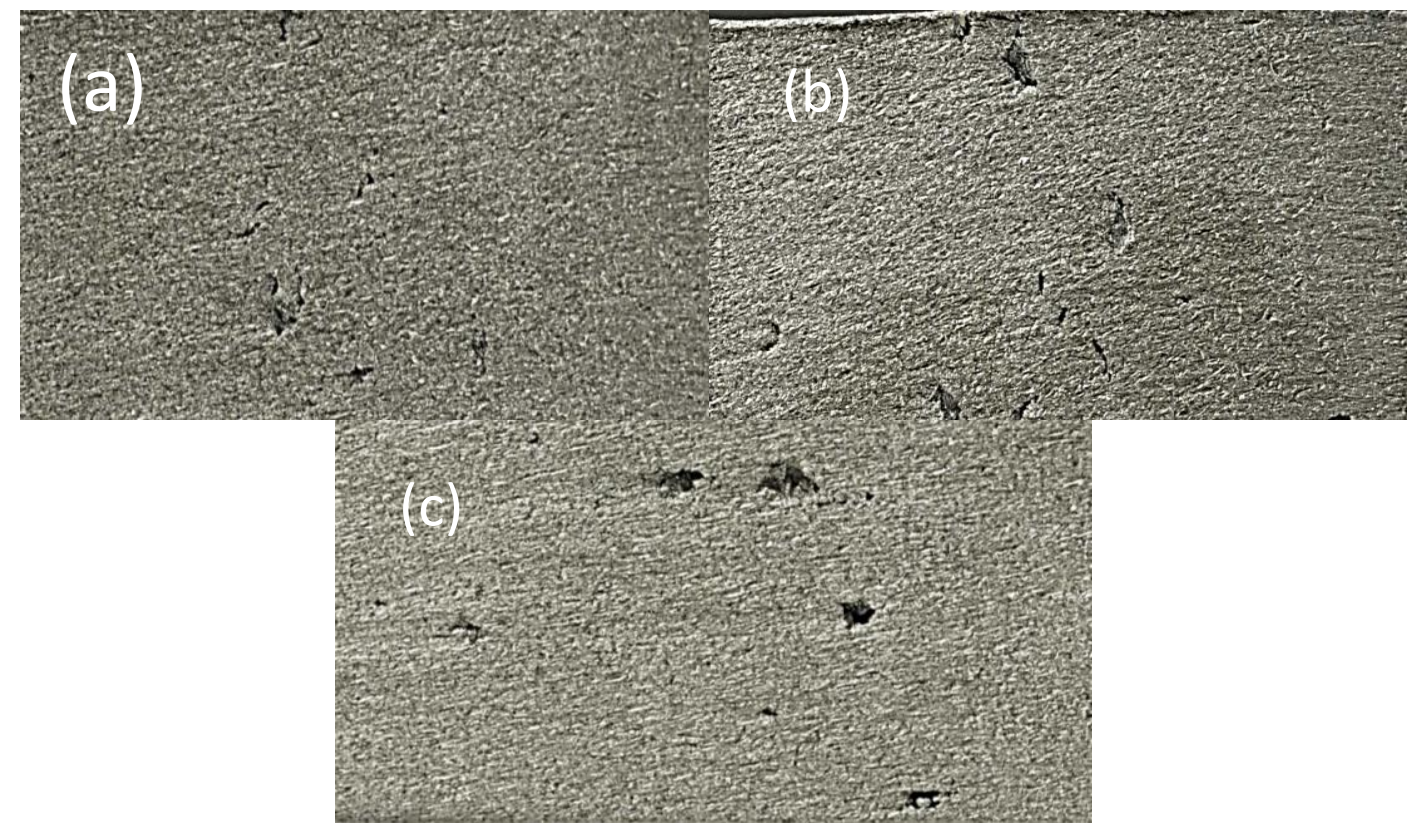

Figure 2. Physical images of $\mathrm{AWJ}$ machined surface for three samples (a) $\mathrm{A} 359 / 2 \% \mathrm{~B}_{4} \mathrm{C} / 2 \% \mathrm{Al}_{2} \mathrm{O}_{3}$, (b) $\mathrm{A} 359 / 3 \% \mathrm{~B}_{4} \mathrm{C} / 3 \% \mathrm{Al}_{2} \mathrm{O}_{3}$ (c) $\mathrm{A} 359 / 4 \% \mathrm{~B}_{4} \mathrm{C} / 4 \% \mathrm{Al}_{2} \mathrm{O}_{3}$

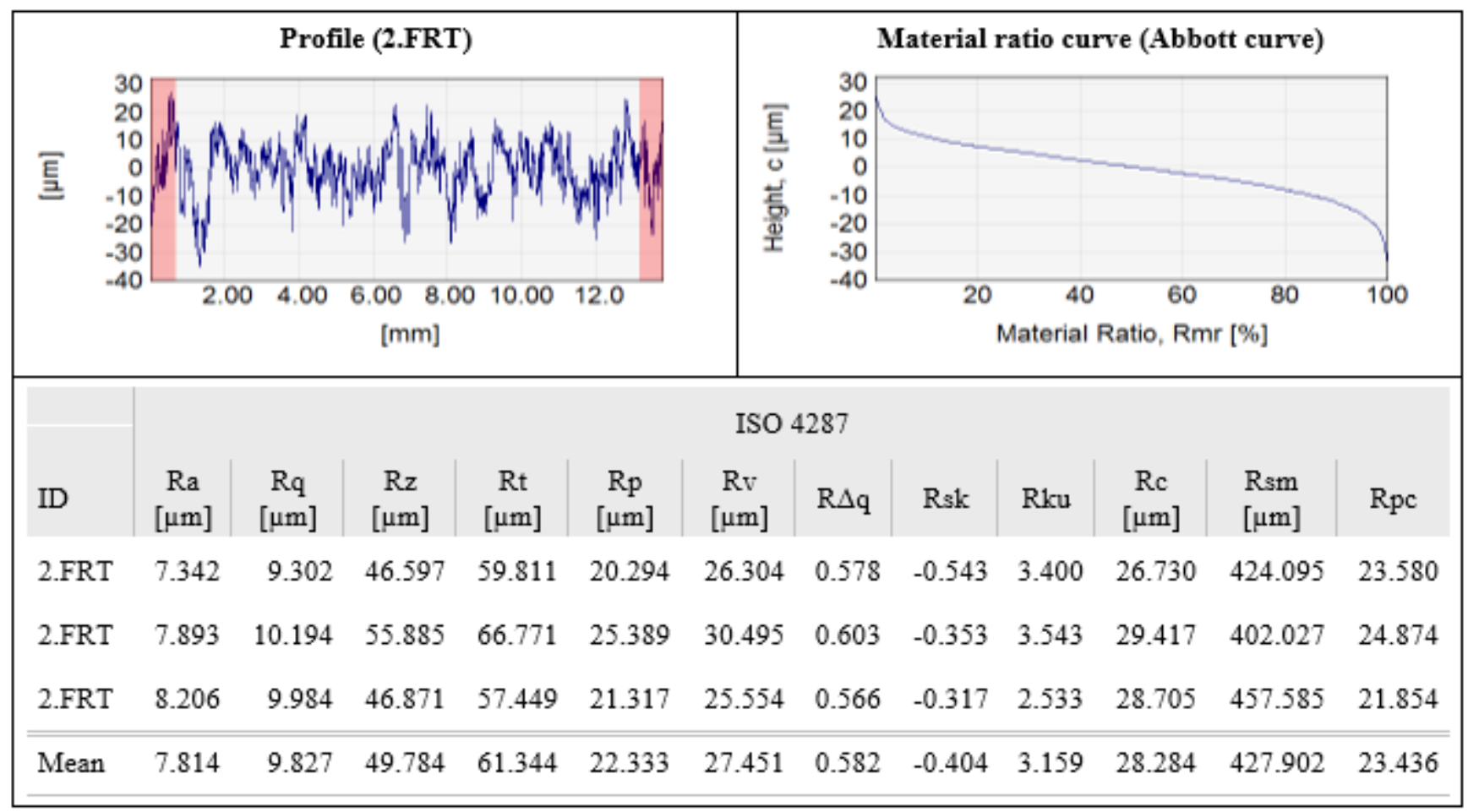

Figure 3. Roughness analysis report for a collection of profiles for sample $\mathrm{A} 359 / 2 \% \mathrm{~B}_{4} \mathrm{C} / 2 \% \mathrm{Al}_{2} \mathrm{O}_{3}$ 


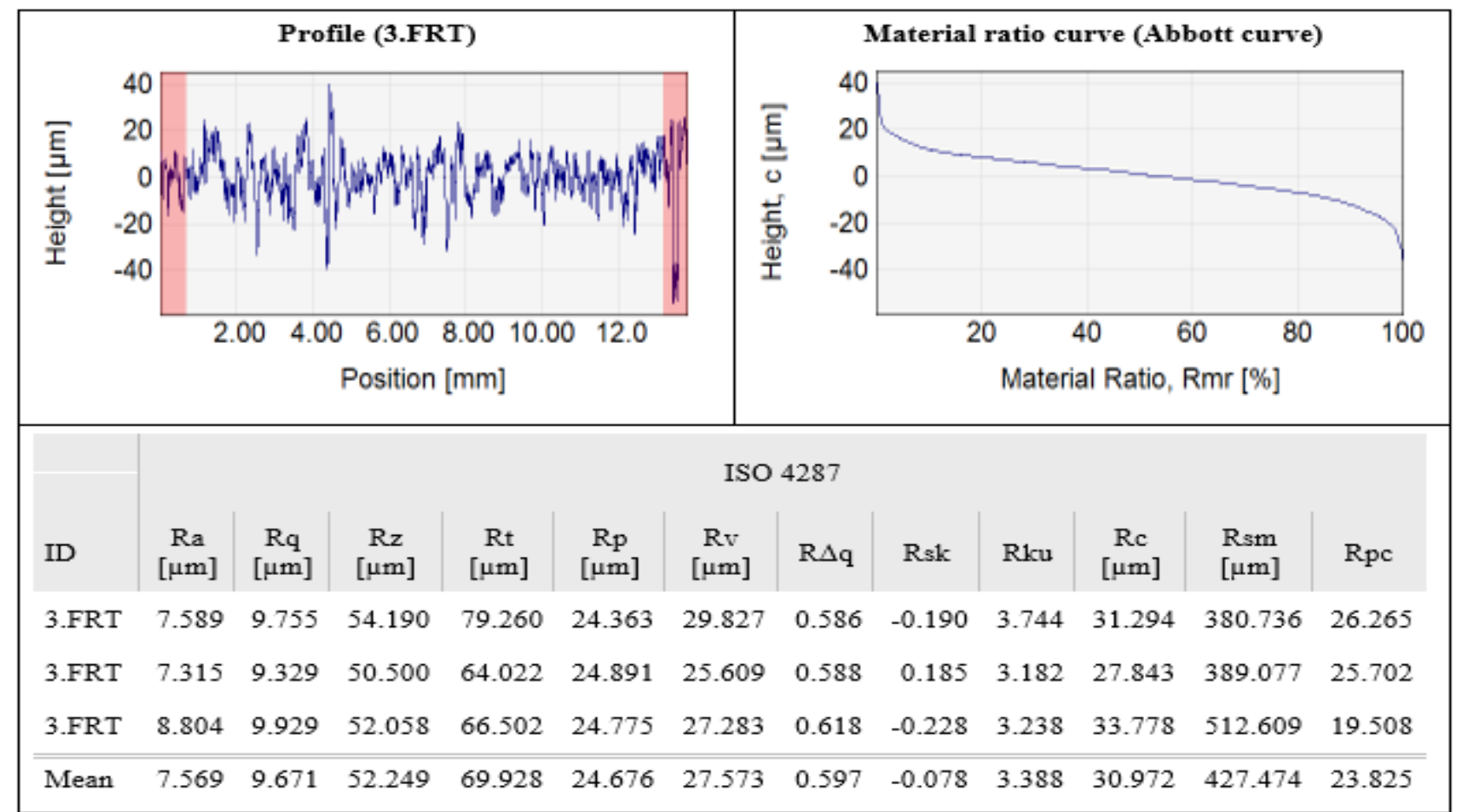

Figure 4. Roughness analysis report for a collection of profiles for sample $\mathrm{A} 359 / 3 \% \mathrm{~B}_{4} \mathrm{C} / 3 \% \mathrm{Al}_{2} \mathrm{O}_{3}$

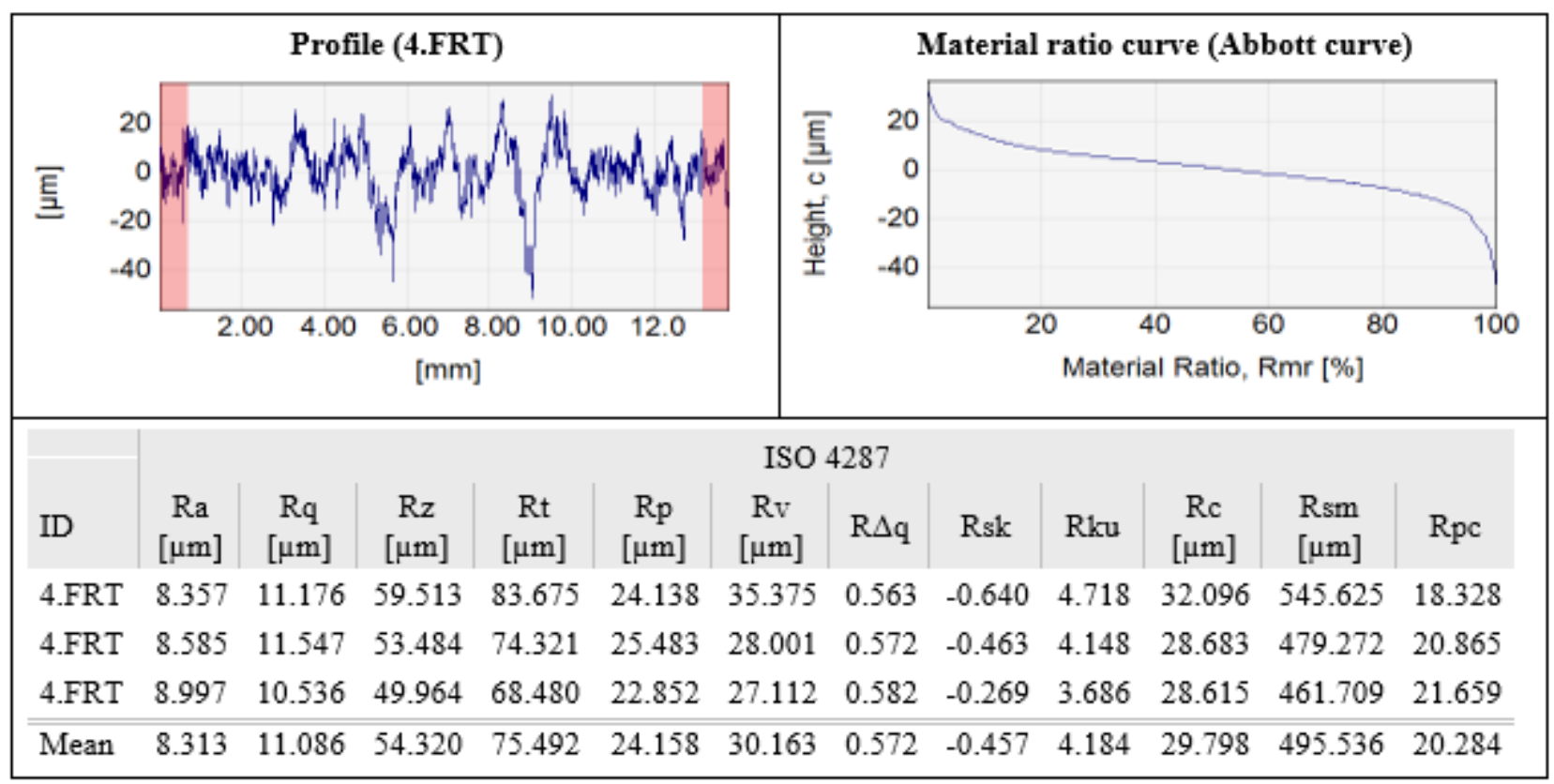

Figure 5. Roughness analysis report for a collection of profiles for sample $\mathrm{A} 359 / 4 \% \mathrm{~B}_{4} \mathrm{C} / 4 \% \mathrm{Al}_{2} \mathrm{O}_{3}$

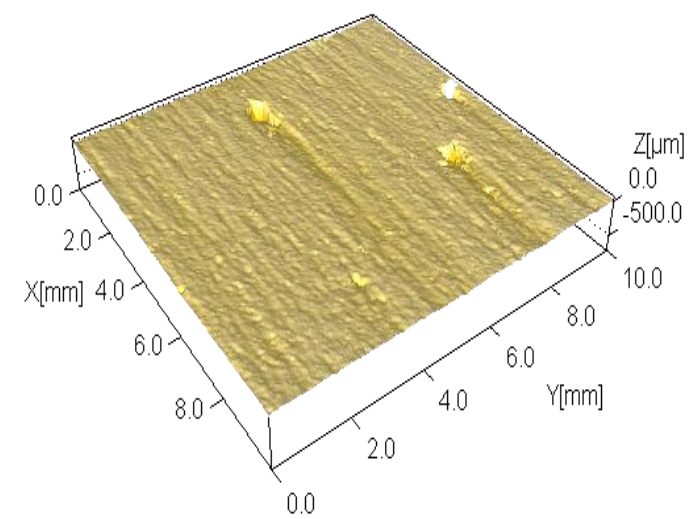

(6a)

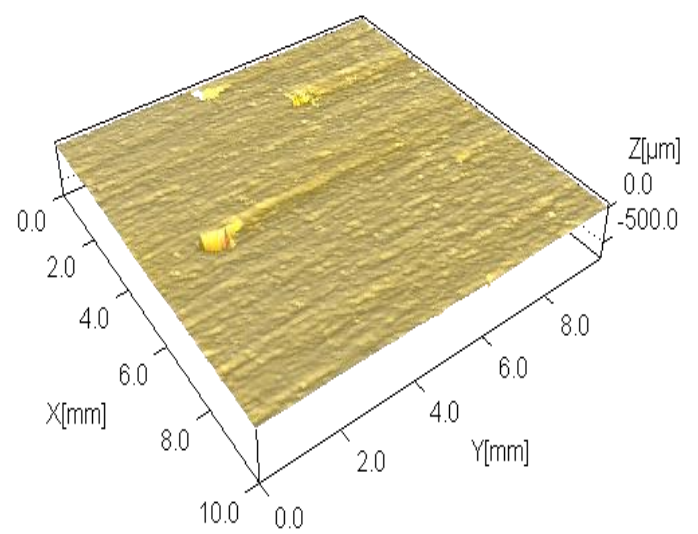

(6b)

Figure 6. (a) $3 \mathrm{D}$ view surface 1 (b) $3 \mathrm{D}$ view surface 2 (rotated $90^{\circ}$ ), sample $\mathrm{A} 359 / 2 \% \mathrm{~B}_{4} \mathrm{C} / 2 \% \mathrm{Al}_{2} \mathrm{O}_{3}$ 


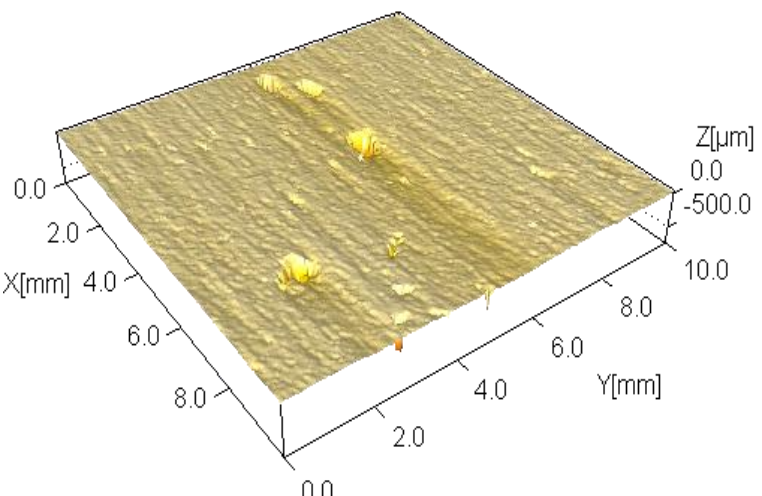

(7a)

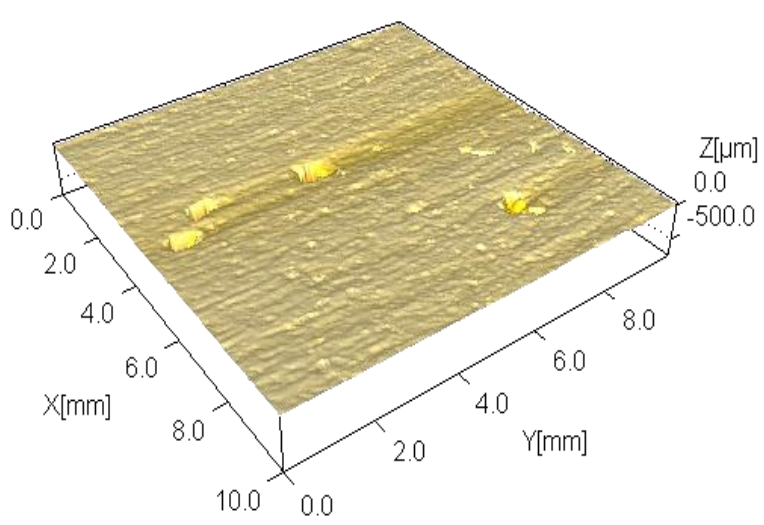

(7b)

Figure 7. (a) $3 \mathrm{D}$ view surface 1 (b) $3 \mathrm{D}$ view surface 2 (rotated $90^{\circ}$ ), sample $\mathrm{A} 359 / 3 \% \mathrm{~B}_{4} \mathrm{C} / 3 \% \mathrm{Al}_{2} \mathrm{O}_{3}$

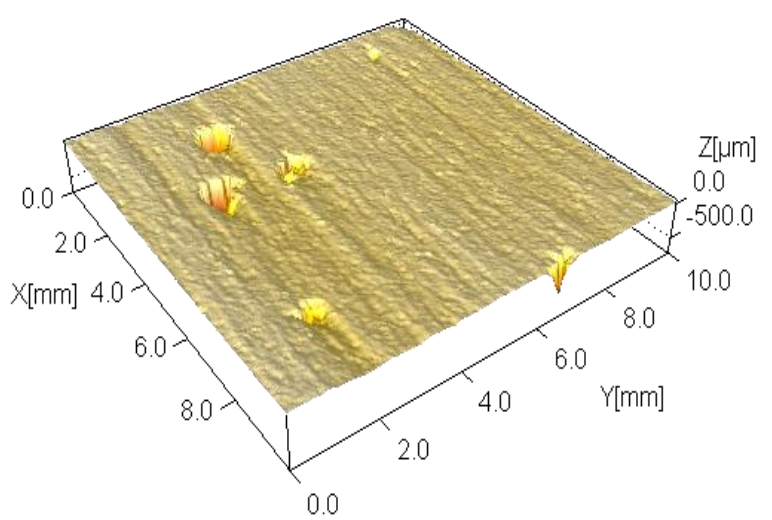

(8a)

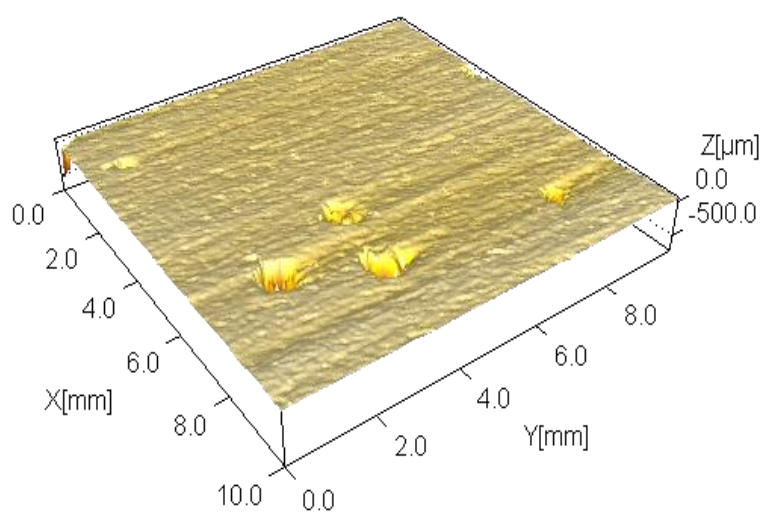

(8b)

Figure 8. (a) $3 \mathrm{D}$ view surface 1 (b) $3 \mathrm{D}$ view surface 2 (rotated $90^{\circ}$ ), sample $\mathrm{A} 359 / 4 \% \mathrm{~B}_{4} \mathrm{C} / 4 \% \mathrm{Al}_{2} \mathrm{O}_{3}$

\section{CONCLUSION}

The machining of all three samples of hybrid MMC was successfully completed. The physical image of the machined surface shows the glossy finish with full of cutting traces. There is no any standard cutting pattern was observed on the machined surface. At last the conclusions of the results are as follows;

[1] The average surface roughness ranges from $7.32 \mu \mathrm{m}$ to $8.2 \mu \mathrm{m}$ for sample $\mathrm{A} 359 / 2 \% \mathrm{~B}_{4} \mathrm{C} / 2 \% \mathrm{Al}_{2} \mathrm{O}_{3}, 7.58 \mu \mathrm{m}$ to $8.80 \mu \mathrm{m}$ for sample $\mathrm{A} 359 / 3 \% \mathrm{~B}_{4} \mathrm{C} / 3 \% \mathrm{Al}_{2} \mathrm{O}_{3}$ and $8.35 \mu \mathrm{m}$ to $8.99 \mu \mathrm{m}$ for sample $\mathrm{A} 359 / 4 \% \mathrm{~B}_{4} \mathrm{C} / 4 \% \mathrm{Al}_{2} \mathrm{O}_{3}$ and. The other surface roughness parameters are also variety in the same order for all three samples.

[2] It is observed that there is a rough cutting by AWJ process. This is due to the fact that during the AWJ process, high speed and high-pressure water jet with full of abrasive strikes the work piece surface. Due to which the surface gets plastically deformed and cutting action seems like ploughing of work piece surface.

[3] The 3D surface profile of the machined surface shows the cutting traces oriented parallel to the direction of jet flow. However, some of the traces are oblique to the direction of jet flow and also randomly oriented.

[4] Macro-pores are observed on the machined surfaces of all three samples. This is due to the fact that while jet strikes the work piece surface the material gets plastically deformed, however the reinforcement particles which are come in the line of jet cutting are pulled out from the matrix material instead of cutting. Due to which the macro-pores are observed on the machined surface.

\section{REFERENCES}

[1] Maurya, M., Maurya, N.K., Bajpai, V. (2019). Effect of $\mathrm{SiC}$ reinforced particle parameters in the development of aluminium based metal matrix composite. EVERGREEN Joint Journal of Novel Carbon Resource Sciences \& Green Asia Strategy, 6(3): 200-206.

[2] Maurya, M., Kumar, S., Bajpai, V. (2019). Assessment of the mechanical properties of aluminium metal matrix composite: A review. Journal of Reinforced Plastics and Composites, 38(6): 267-298. https://doi.org/10.1177/0731684418816379

[3] Maurya, N.K., Maurya, M., Srivastava, A.K., Dwivedi, S.P., Kumar, A., Chauhan, S. (2019). Investigation of mechanical properties of $\mathrm{Al} 6061 / \mathrm{SiC}$ composite prepared through stir casting technique. Materials Today: Proceedings. https://doi.org/10.1016/j.matpr.2019.09.003.

[4] Srivastava, A.K., Dixit, A.R., Tiwari, S. (2016). A review on the intensification of metal matrix composites and its nonconventional machining. Science and Engineering of Composite Materials, 25(2): 18-20. https://doi.org/10.1515/secm-2015-0287

[5] Nag, A., Srivastava, A.K., Dixit, A.R., Mandal, A., Das, A.K. (2018). Surface integrity analysis of wire-EDM on in-situ hybrid composite $\mathrm{A} 359 / \mathrm{Al}_{2} \mathrm{O}_{3} / \mathrm{B} 4 \mathrm{C}$. Materials Today Proceedings, 5(11): 24632-24641. https://doi.org/10.1016/j.matpr.2018.10.261

[6] Srivastava, A.K. (2018). Statistical optimization of wire-EDM during processing of hybrid MMC. International Journal of Mechanical and Production 
Engineering Research and Development (IJMPERD), $8(6)$ : 783-792.

https://doi.org/10.24247/ijmperddec201879

[7] Kumar, N.G.S., Shankar, G.S.S., Basavarajappa, S., Suresh, S.R. (2017). Some studies on mechanical and machining characteristics of Al2219/n-B4C/MoS 2 nanohybrid metal matrix composites. Measurement, 107: 111. https://doi.org/10.1016/j.measurement.2017.05.003

[8] Srivastava, A., Dixit, A.R., Tiwari, S. (2014). Experimental investigation of wire EDM process parameters on aluminium metal matrix composite A12024/SiC. International Journal of Advance Research and Innovation, 2(2): 511-515. https://doi.org/10.4103/2230-8598.144134

[9] Srivastava, A.K. (2018). A description of surfaces created on the hybrid MMC by the AWJ cutting technology. International Journal of Mechanical and Production Engineering Research and Development (IJMPERD), 8(6): 715-720.

[10] Saurabh, S., Tiwari, T., Nag, A., Dixit, A.R., Mandal, N., Das, A.K., Mandal, A., Srivastava, A.K. (2018) Processing of alumina ceramics by abrasive waterjet-an experimental study. Proceedings of Materials Today, 5(9): 18061-18069. https://doi.org/10.1016/j.matpr.2018.06.140

[11] Srivastava, A.K., Nag, A., Dixit, A.R., Tiwari, S. Scucka, J., Zelenak, M., Hloch, S., Hlavacek, P. (2017). Surface integrity in tangential turning of hybrid MMC $\mathrm{A} 359 / \mathrm{B} 4 \mathrm{C} / \mathrm{Al}_{2} \mathrm{O}_{3}$ by abrasive waterjet. Journal of Manufacturing Processes, 28(1): 11-20. https://doi.org/10.1016/j.jmapro.2017.05.017

[12] Mardi, K.B., Dixit, A.R., Srivastava, A.K., Mallick, A., Scucka, J., Hlavacek, P., Hloch, S., Zelenak, M. (2018). Effect of water pressure during abrasive waterjet machining of Mg-based nanocomposite. In: Singh M., Kushvah B., Seth G., Prakash J. (eds) Applications of
Fluid Dynamics. Lecture Notes in Mechanical Engineering. Springer, Singapore. https://doi.org/10.1007/978-981-10-5329-0_46

[13] Nag, A., Srivastava, A.K., Dixit, A.R., Chattopadhyaya, S., Mandal, A., Hlavacek, P., Klichova, D., Zelenak, M., Hloch, S. (2018). Influence of abrasive water jet turning parameters on variation of diameter of hybrid metal matrix composite. Applications of Fluid Dynamics, Springer, pp. 495-504. https://doi.org/10.1007/978-98110-5329-0_36

[14] Nag, A., Ščučka, J., Hlavacek, P., Klichová, D., Srivastava, A.K., Hloch, S., Dixit, A.R., Foldyna, J., Zelenak, M. (2017). Hybrid aluminium matrix composite AWJ turning using olivine and Barton garnet. Int. J. Adv. Manuf. Technol, 94: 2293-2300. https://doi.org/10.1007/s00170-017-1036-0

[15] Srivastava, A.K., Nag, A., Dixit, A.R., Scucka, J., Hloch, S., Klichová, D., Hlaváček, P., Tiwari, S. (2019). Hardness measurement of surfaces on hybrid metal matrix composite created by turning using an abrasive water jet and WED. Measurement, 131: 628-639. https://doi.org/10.1016/j.measurement.2018.09.026

[16] Srivastava, A.K., Nag, A., Dixit, A.R., Tiwari, S., Srivastava, V.S. (2019). Parametric study during abrasive water jet turning of hybrid metal matrix composite. Advances in Manufacturing Engineering and Materials. Lecture Notes in Mechanical Engineering, Springer, pp. 72-84. https://doi.org/10.1007/978-3-31999353-9_9

[17] Tiwari, T., Sourabh, S., Nag, A., Dixit, A.R., Mandal, A., Das, A.K., Mandal, N., Srivastava, A.K. (2018). Parametric investigation on abrasive waterjet machining of alumina ceramic using response surface methodology. Proceedings of Materials Today, 377: 012005. https://doi.org/10.1088/1757-899X/377/1/012005 